\title{
Effect of Wheelchair Tilt-In-Space and Recline Angles on Skin Perfusion Over the Ischial Tuberosity in People With Spinal Cord Injury
}

\author{
Yih-Kuen Jan, PT, PhD, Maria A. Jones, PT, PhD, ATP, Meheroz H. Rabadi, MD, Robert D. \\ Foreman, PhD, and Amy Thiessen, PT, MEd, NCS, ATP \\ From the Department of Rehabilitation Sciences, University of Oklahoma Health Sciences Center \\ (Jan, Jones, Thiessen); Department of Neurology and Rehabilitation, Veterans Affairs Medical \\ Center (Rabadi); and Department of Physiology, University of Oklahoma Health Sciences Center \\ (Jan, Foreman), Oklahoma City, OK.
}

\begin{abstract}
Objective-To investigate the efficacy of wheelchair tilt-in-space and recline on enhancing skin perfusion over the ischial tuberosity in wheelchair users with spinal cord injury (SCI).

Design-Repeated measures, intervention and outcomes measure design.

Setting-A university research laboratory.

Participants-11 wheelchair users with SCI ( 9 men, 2 women; mean age \pm standard deviation, $37.7 \pm 14.2$ years; body mass index $24.7 \pm 2.6 \mathrm{~kg} / \mathrm{m}^{2}$; and duration of injury $8.1 \pm 7.5$ years).

Interventions - 6 protocols of various wheelchair tilt-in-space and recline angles were randomly assigned to the participants. Each protocol consisted of a 5-min sitting-induced ischemic period and a 5-min wheelchair tilt-in-space and recline pressure relieving period. A participant sat in a position without tilt or recline for 5 minutes and then sat in one of 6 wheelchair tiled and reclined positions, including (1) $15^{\circ}$ tilt-in-space and $100^{\circ}$ recline, (2) $25^{\circ}$ tilt-in-space and $100^{\circ}$ recline, (3) $35^{\circ}$ tilt-in-space and $100^{\circ}$ recline, (4) $15^{\circ}$ tilt-in-space and $120^{\circ}$ recline, (5) $25^{\circ}$ tilt-in-space and $120^{\circ}$ recline, and (6) $35^{\circ}$ tilt-in-space and $120^{\circ}$ recline. A 5-min washout period (at $35^{\circ}$ tilt-inspace and $120^{\circ}$ recline) was allowed between protocols.
\end{abstract}

Main Outcome Measures-Laser Doppler flowmetry was used to measure skin perfusion over the ischial tuberosity in response to the changes of body positions caused by performing wheelchair tilt-in-space and recline. Skin perfusion response to wheelchair tilt-in-space and recline was normalized to skin perfusion of the upright seated position (no tilt/recline).

Results-When combined with $100^{\circ}$ recline, wheelchair tilt-in-space at $35^{\circ}$ resulted in a significant increase in skin perfusion as compared with upright seated position (no tilt/recline)

(C) 2010 The American Congress of Rehabilitation Medicine. Published by Elsevier Inc. All rights reserved.

Correspondence to Yih-Kuen Jan, PT, PhD, Dept of Rehabilitation Sciences, University of Oklahoma Health Sciences Center, 1200 N Stonewall Ave, Room 3135, Oklahoma City, OK 73117, yjan@ouhsc.edu. Reprints are not available from the author.

Publisher's Disclaimer: This is a PDF file of an unedited manuscript that has been accepted for publication. As a service to our customers we are providing this early version of the manuscript. The manuscript will undergo copyediting, typesetting, and review of the resulting proof before it is published in its final citable form. Please note that during the production process errors may be discovered which could affect the content, and all legal disclaimers that apply to the journal pertain.

No commercial party having a direct financial interest in the results of the research supporting this article has or will confer a benefit on the authors or on any organization with which the authors are associated.

Suppliers 
$(\mathrm{p}<0.05)$, while there was no significant increase in skin perfusion at $15^{\circ}$ and $25^{\circ}$ tilt-in-space( non significance). When combined with $120^{\circ}$ recline, wheelchair tilt-in-space at $15^{\circ}, 25^{\circ}$, and $35^{\circ}$ tiltin-space all showed a significant increase in skin perfusion as compared with upright seated position $(\mathrm{p}<0.05)$.

Conclusions-Our results indicate that wheelchair tilt-in-space should be at least $35^{\circ}$ for enhancing skin perfusion over the ischial tuberosity when combined with recline at $100^{\circ}$; wheelchair tilt-in-space should be at least $25^{\circ}$ when combined with recline at $120^{\circ}$. Although smaller angles of wheelchair tilt-in-space and recline are preferred by wheelchair users for functional purposes, wheelchair tilt-in-space less than $25^{\circ}$ and recline less than $100^{\circ}$ may not be sufficient for an effective pressure reduction for enhancing skin perfusion over the ischial tuberosities in people with SCI.

\section{Keywords}

Pressure ulcer; Rehabilitation; Spinal cord injuries; Wheelchairs

Pressure ulcers significantly affect the quality of life of wheelchair users with SCI. ${ }^{1}$ The incidence rate of pressure ulcers is over $33 \%$ in acute rehabilitation. ${ }^{2}$ Pressure ulcers are among the most frequent causes of re-hospitalization of people with SCI. ${ }^{3,4}$ It is estimated that over $50 \%$ of people with SCI will develop at least a pressure ulcer in their lifetime. ${ }^{1}$ Annual US treatment costs of pressure ulcers in people with SCI are approximately $\$ 1.3$ billion, accounting for $25 \%$ of the total cost of treating SCI. ${ }^{5}$ It is clear that research regarding the prevention of pressure ulcers remains a priority in people with SCI.

SCI results in various structural and functional changes below the injury level that may predispose individuals to skin breakdown. ${ }^{6}$ Losing the protective mechanism for avoiding prolonged ischemic insults to the compressed tissues is due to the blockade of the sensory pathway to the brain. The sensory loss is the primary factor responsible for a high incidence of pressure ulcers in people with SCI. Deprivation of autonomic nervous system control over the cardiovascular system attenuates the vasodilatory response to loading pressure. Motor spinal injury results in inability to perform pressure reduction activities further aggravating viability of the weight-bearing soft tissues. Motor spinal injury also causes muscle atrophy with a subsequence of a higher seating interface pressure over bony prominences. ${ }^{7}$ These factors directly contribute to the high incidence of pressure ulcers in people with SCI. ${ }^{8}$

Although the precise etiology of pressure ulcers is unknown, several theories have been proposed, including prolonged tissue ischemia following occlusion of capillary blood flow, direct cell death due to contact pressure, increased interstitial fluid pressure, and ischemiareperfusion injury.9 Among these theories, tissue ischemia is generally accepted as a critical factor contributing to the development of pressure ulcers. ${ }^{9}$ Tissue ischemia occurs when externally applied pressure and shear cause the occlusion of blood vessels (e.g. arterioles and capillaries). ${ }^{6}$ If tissue ischemia reaches the threshold of tissue damage, irreversible pressure ulcers develop. 10, 11 The threshold has been shown to be related with the magnitude and duration of pressure by Kosiak 10 and Reswick and Rogers. ${ }^{11}$ They demonstrated that an inverse relationship exists between the magnitude and time of loading pressure in the development of pressure ulcers. Researchers have been attempting to determine a universal threshold in the past years. However, it is unlikely that a threshold will be found due to a variation of risk factors in individuals with SCI.

Based on current research evidence, an essential component of a pressure ulcer prevention program is to periodically reduce seating pressure. ${ }^{12}$ During the pressure reduction period, ischemic soft tissues restore blood flow to meet the metabolic needs of local cells. Various 
methods of pressure reduction activities have been used, such as push-ups, lean forward/side to side, dynamic support surfaces (e.g. alternating pressure), and wheelchair tilt-in-space and recline. ${ }^{13}$ Clinically, pressure relieving activities using wheelchair tilt-in-space and recline is recommended for preventing sitting-induced pressure ulcers in wheelchair users with SCI, especially in people with tetraplegia.12, 14 Several studies have established evidence of seating pressure reduction in tilted and reclined postures. $15^{-20}$ Hobson compared the effect of body postures on interface pressure and shear forces. ${ }^{16}$ The results showed backrest recline to $120^{\circ}$ resulted in $12 \%$ reduction in interface pressure and $25 \%$ increase in shear force; tilt to $20^{\circ}$ resulted in $11 \%$ reduction in interface pressure and elimination of shear forces. Henderson et al. demonstrated an average of $27 \%$ reduction, $47 \%$ reduction, and $78 \%$ reduction in maximum interface when the participants with $\mathrm{SCI}$ in the $35^{\circ}$ tilt, $65^{\circ}$ tilt and forward lean postures, respectively. Burns et al. demonstrated that $45^{\circ}$ tilt resulted in a $45 \%$ reduction of interface pressure over the ischial tuberosity. ${ }^{19}$ In a study conducted by Vaisbuch et al., they showed that $25^{\circ}$ tilt resulted in $22 \%$ reduction. A recent systemic review concluded that at least $20^{\circ}$ tilt is needed to effectively reduce interface pressure..$^{21}$

Although evidence regarding the use of wheelchair tilt-in-space and recline to reduce seating interface pressure exists, ${ }^{16}, 18,21-23$ the exact impact on skin blood flow and tissue viability is unclear. ${ }^{24,}{ }^{25}$ Furthermore, inadequate pressure reduction by wheelchair tilt-in-space and recline may not benefit ischemic tissues. ${ }^{26}$ Several investigators have drawn attention to the limitations of interface pressure in determining efficacy of seating conditions and have emphasized the importance of other factors, for example, skin blood flow. ${ }^{27-29}$ In support of skin blood flow measures over interface pressure, Frantz and Xakellis concluded that, "by using perfusion as the assessment parameter, variation in individual physiological response to compressive surface pressure could be identified more accurately and high risk conditions averted." ${ }^{30}$ Moreover, skin blood flow response to loading pressure has shown promise to guide the development of support surfaces for preventing pressure ulcers. ${ }^{31}, 3233$ Schubert and Fagrell showed that people with SCI had a smaller increase in skin perfusion during a reactive hyperemic response as compared with healthy controls. This characteristic was attributed to as a risk factor of pressure ulcers. ${ }^{33} \mathrm{Jan}$ et al. demonstrated that the loading pressure pattern affects skin perfusion responses in weight-bearing tissues. ${ }^{31}$ Under the same average pressure, alternating pressure enhances skin perfusion as compared with constant pressure in people with SCI. Makhsous et al. compared the efficacy of various pressure reduction methods on interface pressure and tissue perfusion and concluded that tissue perfusion may be a more effective indicator in assessing pressure reduction strategies. ${ }^{32}$ The use of tissue perfusion to evaluate the efficacy of wheelchair tilt-in-space and recline may establish a guideline to reduce risk for pressure ulcers.

The Rehabilitation Engineering and Assistive Technology Society of the North America published a clinical guideline to clarify the use of wheelchair tilt-in-space and recline. 34 The guideline indicates that wheelchair tilt-in-space and recline should be recommended for wheelchair users at risk for pressure ulcers. The need to study the effectiveness of wheelchair tilt-in-space and recline was also indicated by a recent systemic review on the wheelchair tilt system. ${ }^{21}$ In order to understand the specific benefits associated with wheelchair tilt-in-space and recline, more research studies are needed to study the efficacy of various settings (angles, frequencies, and durations) of wheelchair tilt-in-space and recline on tissue viability. Once evidence of using wheelchair tilt-in-space and recline has been established, wheelchair users at risk for pressure ulcers will be able to receive these power systems through healthcare reimbursement.

In responding to The Rehabilitation Engineering and Assistive Technology Society of the North America's request, we have designed a series of studies to investigate the effectiveness of wheelchair tilt-in-space and recline on enhancing skin perfusion in 
wheelchair users with SCI. The purpose of this study was to investigate skin blood flow over the ischial tuberosity in response to changes of body positions induced by performing wheelchair tilt-in-space at three angles $\left(15^{\circ}, 25^{\circ}\right.$, and $\left.35^{\circ}\right)$ in combination with wheelchair recline at two angles $\left(100^{\circ}\right.$ and $\left.120^{\circ}\right)$. By comparing these commonly used wheelchair tiltin-space and recline angles, we intended to understand the efficacy of wheelchair tilt-inspace and recline angles on enhancing skin perfusion and potential risk for pressure ulcers in wheelchair users with SCI.

\section{METHODS}

A repeated measures, intervention and outcomes measure research design was used in this study.

\section{Participants}

A total of 11 wheelchair users with SCI were recruited into the study. The participants were recruited through research flyers or referring from clinicians in the University Of Oklahoma Health Sciences Center Lokomat Clinic and the Jim Thorpe Rehabilitation Hospital in Oklahoma. The inclusion criteria included traumatic spinal cord injury at the level between $\mathrm{C} 4$ and T12, post spinal injury at least 6 months, use of wheelchair as a primary means of mobility, and wheelchair seat width between 17" and 21." The exclusion criteria included cardiorespiratory diseases or other diseases that may affect cardiovascular function, diagnosed skeletal deformities (scoliosis, pelvic obliquity, and hip and knee contracture), and active pressure ulcers. All participants gave informed consent to this study approved by the University Institutional Review Board. The demographic data of participants were as follows (values are mean \pm standard deviation): age $37.7 \pm 14.2$ years; body mass index $24.7 \pm$ $2.6 \mathrm{~kg} / \mathrm{m}^{2}$; and duration of injury $8.1 \pm 7.5$ years. The 11 wheelchair users included 2 females and 9 males; 1 African-American, 1 American-Indian, and 9 Caucasian. 4 participants had sensory complete injury (ASIA A), 2 participants had motor complete injury (ASIA B), and 5 participants had incomplete injury (ASIA C and D). All participants used power wheelchair for mobility.

\section{Apparatus}

$\mathrm{LDF}^{\mathrm{a}}$ was used to measure skin perfusion in arbitrary unit (or loosely defined as skin blood flow in clinical usage). ${ }^{13} \mathrm{~A}$ thin LDF probe ${ }^{\mathrm{b}}$ was used to measure perfusion on the skin over the right ischial tuberosity. LDF provides noninvasive, real-time measurement of skin perfusion at a depth of about $1 \mathrm{~mm}$ via laser and fiber optics technology. LDF emits monochromatic laser light to the skin. Based on the spectrum of the reflected light, LDF can calculate the changes of blood flow velocity using the Doppler principle. ${ }^{35}$ Since LDF only measures skin perfusion in a small area, the skin perfusion is cofounded by spatial variations of cutaneous microcirculation. ${ }^{36}$ Another limitation of LDF is unable to detect deeper muscle perfusion, which is associated with deep tissue injury. The advantage of using LDF to assess skin viability is due to its non-invasive nature. In the current literature, it is well accepted that an increase in skin perfusion is accompanied with an increase in oxygenation level. Skin perfusion was sampled at $32 \mathrm{~Hz}$ for additional off-line analysis. The use of LDF can detect the changes of skin viability in response to wheelchair tilt-in-space and recline, which provides a more direct assessment than the interface pressure measurement in the aspect of pressure ulcer development. ${ }^{9}$ A power wheelchair with tilt-in-space and recline functions ${ }^{c}$ was used in this study. Seat width was 19 ". A high density foam cushion ${ }^{\mathrm{d}}$ was

\footnotetext{
aPeriflux system 5001, Perimed, Sweden.

b 2415 probe, Perimed, Sweden.

${ }^{\mathrm{C}}$ Power wheelchair C300 Corpus, Permobil, Inc., Lebanon, TN.
} 
used in this study. The wheelchair tilt-in-space was defined as "a change of seat angle orientation in relation to the ground while maintaining the seat to back angle." 34 In this study, tilt referred to backward tilt only. The wheelchair recline was defined as "a change in seat to back angle while maintaining a constant seat angle with respect to the ground." 34 The configurations of wheelchair tilt-in-space and recline is shown in Figure 1. Two angle gauges ${ }^{\mathrm{e}}$ were used to measure the angles of wheelchair tilt-in-space and recline.

\section{Procedure}

Room temperature was maintained at $23 \pm 2{ }^{\circ} \mathrm{C}$. Participants were kept in the laboratory for at least 30 minutes to accommodate the room temperature. This step allowed us to minimize the influences of skin temperature on skin perfusion, which is dependent on the environmental temperature. ${ }^{37}$ During the acclimation period, participants with SCI were asked to empty their bladders. The participant was transferred to the mat table to tape the LDF probe onto the skin over the right ischial tuberosity. Then, he/she was transferred to the test power wheelchair with tilt-in-space and recline functions. Regarding the procedures of applying probes, a participant was positioned in the side-lying posture with hips and knees flexed at 90 degrees. By palpating left ischial tuberosity at this posture, the laser Doppler probe was tapped on the skin over the ischial tuberosity. We were not able to accurately detect whether the LDF probe was displaced during the experiment. However, we did not notice any significant displacement after the experiment when removing the LDF probe. Before the testing, the participants sat at $35^{\circ}$ tilt-in-space and $120^{\circ}$ recline for a duration of 5 minutes.

\section{Wheelchair Tilt-in-space and Recline Protocols}

To determine the effects of wheelchair tilt-in-space and recline settings on skin perfusion response to sitting-induced pressure, we selected commonly used angles by wheelchair users, including tilt-in-space at $15^{\circ}, 25^{\circ}$, and $35^{\circ}$ and recline at $100^{\circ}$ and $120^{\circ} 26,3814$. A combination of 3 tilt-in-space and 2 recline angles resulted in 6 testing conditions (Table 1). The order of the 6 testing conditions was randomly assigned to the participant. In order to minimize the sequence effects, we used a balance design to implement the randomization of testing protocols (Table 2). In order to minimize the carry over effect, we used two methods, including a wash out period and a normalization of skin perfusion. A wash out period was for $5 \mathrm{~min}$ at $35^{\circ}$ tilt and $120^{\circ}$ recline. Such arrangement was based on a fact that a duration of reactive hyperemia is proportional to the time of occlusion (5-min tilted and reclined period). For a partial pressure relief, the recovery time is supposed to be longer. Thus, additional 5-min wash out period was used ${ }^{39}$. The other method is to normalize the vasodilatory response to the baseline skin perfusion (ie. skin perfusion before performing wheelchair tilt and recline) $28,31,36$.

The same person performed the adjustment of wheelchair tilt-in-space and recline angles across this study. The range of acceptable angles was plus minus $2^{\circ}$ of the set angle. Each condition lasted for $10 \mathrm{~min}$, including $5 \mathrm{~min}$ sitting-induced ischemic period (no tilt or recline, sacrum close to the seat back, and hands on the thighs) and 5 min pressure reduction period caused by performing wheelchair tilt-in-space and recline. Between each condition, the participants satat $35^{\circ}$ tilt-in-space and $120^{\circ}$ recline for a duration of 5 minutes to restore blood flow supply. ${ }^{29}, 32$ Each participant spent about 2 hours completing the experiment. An example of a complete protocol was provided (Figure 2).

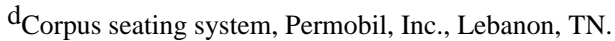

${ }^{\text {e }}$ ixey digital angle gauge, Model WR300, WWW.WIXEY.COM online store.
} 
Based on the characteristics of a postocclusive reactive hyperemic response, we selected 5 minutes for a sitting-induced ischemic period, a tilted and reclined period, and a wash-out period, respectively. It is widely accepted that 5-min occlusion is able to induce a maximal reactive hyperemic response ${ }^{40}$; thus, an ischemic period was selected for 5 minutes. The duration of a reactive hyperemic response is proportional to the period of ischemic occlusion 39-42. Thus, we chose 5 minutes for assessing the efficacy of wheelchair tilt and recline on enhancing skin perfusion. Since wheelchair tilt and recline only provided partial pressure relief, a prolonged reactive hyperemia was expected. Thus, we have chosen another 5 minutes as a wash out period for restoring skin perfusion.

In this study, we did not have recline-only or tilt-in-space-only protocol because a combination of tilt-in-space and recline has shown to be superior to sole use of either wheelchair tilt-in-space or recline.16, 20, ${ }^{34}$ Hobson demonstrated that recline-alone reduced seating interface pressure (interface pressure) but increased shear force. ${ }^{16}$ Shear force is especially harmful for vessel occlusion of weight-bearing soft tissues. 43 A combination of tilt-in-space and recline has been shown to provide the most pressure relief.20

\section{Statistical Analysis}

Skin perfusion over the right ischial tuberosity was continuously measured throughout the study. Skin perfusion during the sitting-induced ischemia period (no tilt-in-space or recline performed) was quantified to establish the baseline perfusion value. The change of skin perfusion in response to changes in body positions caused by performing wheelchair tilt-inspace and recline was normalized to each participant's skin perfusion. To minimize the influences of movement artifact on skin perfusion, we did not average the first 30 seconds of each 5 min period. The rationale for selecting 30 seconds was based on our experiment because a $30 \mathrm{sec}$ period was needed to complete the adjustment of wheelchair tilt-in-space and recline. In this study, an increase of skin perfusion during the pressure relieving period was considered beneficial for the weight-bearing soft tissues. ${ }^{9}, 28 \mathrm{~A}$ one-way analysis of variances with repeated measures design was used to examine the effectiveness of wheelchair tilt-in-space and recline on enhancing skin blood flow over the ischial tuberosity in wheelchair users with SCI. Bonferroni correction was used for post-hoc analysis. All statistical tests were performed at an alpha level of 0.05 . All data were analyzed by using SPSS $16^{\mathrm{f}}$.

\section{RESULTS}

\section{Tilt-in-space angle effect}

When combined with $100^{\circ}$ recline, wheelchair tilt-in-space at $35^{\circ}$ resulted in a significant increase in skin perfusion as compared with wheelchair tilt-in-space at $15^{\circ}$ and $25^{\circ}(\mathrm{p}<0.05)$, while no significant increase in skin perfusion occurred at $15^{\circ}$ and $25^{\circ}$ tilt-in-space (nonsignificant) (Figure 3).

When combined with $120^{\circ}$ recline, wheelchair tilt-in-space at $15^{\circ}, 25^{\circ}$ and $35^{\circ}$ tilt-in-space showed a significant increase in skin perfusion $(\mathrm{p}<0.05)$; and $35^{\circ}$ tilt-in-space resulted in a significant increase in skin perfusion when compared with $15^{\circ}$ tilt-in-space $(\mathrm{p}<0.05)$ (Figure $3)$.

\section{Recline angle effect}

When combined with $15^{\circ}$ tilt-in-space, $120^{\circ}$ recline did not induce a significant increase in skin perfusion as compared with $100^{\circ}$ recline (NS) (Figure 3)

f SPSS, Inc, $233 \mathrm{~S}$ Wacker Dr, $11^{\text {th }}$ Fl, Chicago, IL 60606. 
When combined with $25^{\circ}$ tilt-in-space, $120^{\circ}$ recline induced a significant increase in skin perfusion as compared with $100^{\circ}$ recline $(\mathrm{p}<0.05)$ (Figure 3).

When combined with $35^{\circ}$ tilt-in-space, $120^{\circ}$ recline induced a significant increase in skin perfusion as compared with $100^{\circ}$ recline $(\mathrm{p}<0.05)$ (Figure 3$)$.

\section{DISCUSSION}

The main finding of this study is that our results confirm the use of wheelchair tilt-in-space and recline in sufficient magnitude to reduce skin ischemia over the ischial tuberosity in wheelchair users with SCI. Our results indicate that larger angles of tilt-in-space and recline resulted in a larger increase in skin perfusion, while wheelchair tilt-in-space less than $25^{\circ}$ in combination with recline at $100^{\circ}$ may not be sufficient for an effective pressure reduction for enhancing skin perfusion. Although the literature has established evidence that wheelchair tilt-in-space and recline reduce seating interface pressure in wheelchair users, its efficacy on enhancing skin viability has not been investigated. The current clinical practice assumed that a reduction of seating pressure is associated an increase in skin and muscle perfusion, thus reducing risk for pressure ulcers. Our study provides first evidence that wheelchair tilt-in-space and recline in sufficient angles reduces skin ischemia. This evidence will help promote the use of wheelchair tilt-in-space and recline for reducing risk for pressure ulcers in wheelchair users with SCI Interface pressure between buttock and seat cushion have been widely used to evaluate the effectiveness of various pressure reduction strategies, such as wheelchair cushions, tilt-in-space and recline, push-ups, forward and side leaning. 6 These findings have long been used by clinicians to select various pressure relieving strategies and products. Whether a reduction in interface pressure is accompanied by a linear reduction in skin perfusion remains largely unknown. ${ }^{34}$ If a reduction of interface pressure does not allow for a vasodilatory response, the use of wheelchair tilt-in-space and recline may not reduce risk for pressure ulcers. In this study, we demonstrated that small angles (e.g. less than $15^{\circ}$ tilt-in-space and $100^{\circ}$ recline) of wheelchair tilt-in-space and recline did not cause an increase in skin perfusion. However, Aissaoui et al. showed that a reduction of about $10 \%$ on peak pressure over the ischial tuberosity at $30^{\circ}$ TIS and $100^{\circ}$ recline. ${ }^{15}$ This finding indicates a need to investigate the relationship between pressure reduction and skin perfusion changes under tilted and recline positions. In order to further understand the efficacy of wheelchair tilt-in-space and recline on reducing risk for pressure ulcers, there is a need to systemically research the efficacy of various angles of wheelchair tilt-in-space and recline on reducing skin and muscle ischemia.34

Skin perfusion was used to assess the efficacy of wheelchair tilt-in-space and recline on reducing risk for pressure ulcers in this study. A transient increase in skin blood flow after ischemia is regulated by a protective mechanism called reactive hyperemia. $39^{-} 42,44$ Reactive hyperemia is mediated mainly by local blood flow control mechanisms (e.g. metabolic control and myogenic response). 6,45 Thus, people with SCI still show a reactive hyperemic response after blood occlusion. 33 Both the magnitude and duration of the reactive hyperemia have been shown to relate to the magnitude and duration of the external loads.40 Under total relief of occlusion, peak blood flow of a hyperemic response may reach more than 10-fold of baseline blood flow. However, under partial pressure reduction, peak blood flow of a reactive hyperemic response becomes smaller.39 When performing wheelchair tilt-in-space and recline, a reduction of interface pressure allows for the development of reactive hyperemia to re-perfuse the ischemic tissues.32 If a reduction of interface pressure is not adequate, reactive hyperemic response may not occur, which may lead to tissue necrosis. ${ }^{9}$ Based on our results, we demonstrated that a setting of wheelchair tilt-in-space and recline may reduce interface pressure $\left(25^{\circ}\right.$ tilt-in-space and $100^{\circ}$ recline) based on a study conducted by Aissaoui et al,,${ }^{15}$ but did not show a reactive hyperemic 
response for reducing skin ischemia. In addition to the existing literature on interface pressure and wheelchair tilt-in-space and recline, our study suggests the use of skin perfusion to guide the development of clinical guidelines of wheelchair tilt-in-space and recline.

Wheelchair tilt-in-space angles between $15^{\circ}$ and $30^{\circ}$ are commonly performed by wheelchair users for pressure relief despite larger angles are clinically recommended. ${ }^{26}, 38$ 14 According to seating interface pressure research, tilt-in-space angles should be at least $15^{\circ}$ for effectively reducing interface pressure. However, our results indicate that the tilt-inspace angle needs to be at least $35^{\circ}$ when combined with $100^{\circ}$ recline, or at least $25^{\circ}$ when combined with $120^{\circ}$ recline for enhancing skin perfusion. Our study suggests that the sole use of tilt-in-space at $15^{\circ}$ is not adequate to allow the development of a vasodilatory response. Such finding has an impact on alerting wheelchair users that a larger angle is needed for reducing skin ischemia. According to recent studies, 38 , 46 wheelchair users usually operate tilt-in-space and recline functions at smaller angles (e.g. less than $15^{\circ}$ ). The use of tilt-in-space and recline at these ranges does not enhance skin perfusion based on our results. Thus, clinicians need to pay more attention on the compliance of wheelchair users on using larger tilt-in-space and recline angles to benefit ischemic tissues over the ischial tuberosity. Adherence to the use of wheelchair tilt-in-space and recline is a critical step to reduce risk for pressure ulcers in wheelchair users with SCI. Long-term monitoring of wheelchair tilt-in-space and recline usage has shown that wheelchair users tend to perform at a smaller range (less than $15^{\circ}$ ).38, 46 Different technologies (eg. audio/visual feedback of achieving targeted tilt-in-space angle, user perception of tilt-in-space angle) may be explored to improve user compliance of using wheelchair tilt-in-space and recline. According to our results, we may partly explain a high incidence of pressure ulcers in wheelchair users with SCI, even after using power tilt-in-space and recline.

Wheelchair recline has been shown to cause shear force in the interface of buttock and seat cushion. ${ }^{16}$ Shear force is also one of the causative factors of pressure ulcers. ${ }^{6,}{ }^{43}$ Dinsdale found that a lower pressure is needed to cause ulcerations in animals when pressure has been combined with shear, as compared with interface pressure only.$^{47}$ Clinicians need to educate wheelchair users not to rely solely on the recline function for pressure ulcer prevention. The use of recline function should be in combination with tilt-in-space function.

Under the same angle of tilt-in-space, a combination of wheelchair recline provides the best pressure relief for enhancing skin perfusion. ${ }^{15,20,48}$ Our results showed a consistent finding with these previous research. Vaisbuch et al. found that a combination of $25^{\circ}$ tilt-in-space and $110^{\circ}$ recline could effectively reduce interface pressure. ${ }^{20}$ Aissaoui et al. demonstrated that a combined position of $45^{\circ}$ tilt-in-space and $120^{\circ}$ recline reduced $40 \%$ of interface pressure. ${ }^{49} \mathrm{~A}$ combination of wheelchair tilt-in-space and recline provides additional option for wheelchair users to select a setting for comfort and enhancing skin viability. Based on the current literature, it is unclear whether there is an interaction between tilt-in-space and recline on enhancing skin perfusion.

\section{Study Limitations}

First, we used skin perfusion to assess the effectiveness of various settings of wheelchair tiltin-space and recline. Although many other factors also contribute to the development of pressure ulcers in people with SCI, soft tissue ischemia is well accepted as the final common pathway of pressure ulcers. If performing pressure relieving activities (wheelchair tilt-inspace and recline) enhances skin perfusion, risk for pressure ulcers may be lowered. However, whether an increase in skin perfusion associated with wheelchair tilt-in-space and recline reduces the incidence of sitting-induced pressure ulcers requires further research. Also, LDF used in this study cannot detect muscle perfusion, which is related wit deep tissue 
injury. Furthermore, we assumed that an increase in skin perfusion is accompanied with an increase in oxygenation level. Second, we used a standard foam cushion from the Permobil. Future studies need to consider the use of different cushions to examine their pressure relieving performance. At this stage, our research should only be applied to foam-based cushions. Third, we only recruited 11 wheelchair users with SCI into this study. Because this was a feasibility study, we intended to examine whether our protocols could be used to assess the efficacy of wheelchair tilt-in-space and recline on enhancing skin perfusion. A larger sample size using this protocol should be conducted to verify our results. Last, although we used one wheelchair in this study, the dimensions of the seating system fit all participants. However, future studies may need to expand the number of participants and incorporate different wheelchair seats sizes.

\section{CONCLUSIONS}

Our results indicate that wheelchair tilt-in-space should be at least $35^{\circ}$ when combined with recline at $100^{\circ}$; wheelchair tilt-in-space should be at least $25^{\circ}$ when combined with recline at $120^{\circ}$. Although smaller angles of wheelchair tilt-in-space and recline are preferred by wheelchair users for functional purposes, wheelchair tilt-in-space should be at least $25^{\circ}$ and recline should be at least $120^{\circ}$ for an effective reduction of interface pressure over the ischial tuberosities in people with SCI. Our findings may help clinicians recommend more specific wheelchair tilt-in-space and recline angles to prevent pressure ulcers.

\section{Acknowledgments}

Supported by the National Institutes of Health (grant no. R03HD060751) and the Oklahoma Presbyterian Health Foundation Seed Grant Program (grant no. PHF1545).

\section{List of Abbreviations}

$\begin{array}{ll}\text { ASIA } & \text { American Spinal Injury Association } \\ \text { LDF } & \text { laser Doppler flowmetry } \\ \text { SCI } & \text { spinal cord injury }\end{array}$

\section{REFERENCES}

1. National Pressure Ulcer Advisory Panel. Pressure Ulcers in America: Prevalence, Incidence, and Implications for the Future. Reston, VA: National Pressure Ulcer Advisory Panel; 2001.

2. National Spinal Cord Injury Statistical Center. Annual Report for the Spinal Cord Injury Model Systems (Public Version). Birmingham, AL: University of Alabama; 2006.

3. Krause JS, Vines CL, Farley TL, Sniezek J, Coker J. An exploratory study of pressure ulcers after spinal cord injury: relationship to protective behaviors and risk factors. Archives of Physical Medicine \& Rehabilitation 2001;82(1):107-113. [PubMed: 11239295]

4. Garber SL, Rintala DH. Pressure ulcers in veterans with spinal cord injury: A retrospective study. Journal of Rehabilitation Research and Development 2003 Sep-Oct;40(5):433-441. [PubMed: 15080228]

5. Byrne DW, Salzberg CA. Major risk factors for pressure ulcers in the spinal cord disabled: a literature review. Spinal Cord 1996;34(5):255-263. [PubMed: 8963971]

6. Jan, YK.; Brienza, D. Tissue mechanics and blood flow factors in pressure ulcers of people with spinal cord injury. In: Gefen, A., editor. The Pathomechanics of Tissue Injury and Disease, and the Mechanophysiology of Healing: Research Signpost. 2009. p. 241-259.

7. Wu GA, Bogie K. Assessment of Gluteus Maximus Muscle Area With Different Image Analysis Programs. Archives of Physical Medicine and Rehabilitation 2009 Jun;90(6):1048-1054. [PubMed: 19480883] 
8. Garber SL, Rintala DH, Hart KA, Fuhrer MJ. Pressure ulcer risk in spinal cord injury: predictors of ulcer status over 3 years. Archives of Physical Medicine \& Rehabilitation 2000;81(4):465-471. [PubMed: 10768537]

9. Nixon J, Cranny G, Bond S. Pathology, diagnosis, and classification of pressure ulcers: comparing clinical and imaging techniques. Wound Repair \& Regeneration 2005;13:365-372. [PubMed: 16008725]

10. Kosiak M. Etiology and pathology of ischemic ulcers. Archives of Physical Medicine \& Rehabilitation 1959;40:62-69. [PubMed: 13618101]

11. Reswick, JB.; Rogers, JE. Experience at Rancho Los Amigos hospital with devices and techniques to prevent pressure sores. In: Kenedi, RM.; Cowden, JM.; Scales, JT., editors. Bedsore Biomechanics. Baltimore: University Park Press; 1976.

12. Reddy M, Gill SS, Rochon PA. Preventing pressure ulcers: a systematic review. Jama 2006;296(8): 974-984. [PubMed: 16926357]

13. Jan YK, Brienza DM. Technology for pressure ulcer prevention. Topics in Spinal Cord Injury Rehabilitation 2006;11(4):30-41.

14. Lacoste M, Weiss-Lambrou R, Allard M, Dansereau J. Powered tilt/recline systems: why and how are they used? Assistive Technology 2003;15(1):58-68. [PubMed: 14760982]

15. Aissaoui R, Lacoste M, Dansereau J. Analysis of sliding and pressure distribution during a repositioning of persons in a simulator chair. IEEE Transactions on Neural Systems \& Rehabilitation Engineering 2001;9(2):215-224. [PubMed: 11474974]

16. Hobson DA. Comparative effects of posture on pressure and shear at the body-seat interface. Journal of Rehabilitation Research \& Development 1992;29(4):21-31. [PubMed: 1432724]

17. Sprigle S, Maurer C, Sorenblum SE. Load Redistribution in Variable Position Wheelchairs in People With Spinal Cord Injury. Journal of Spinal Cord Medicine 2010 Feb;33(1):58-64. [PubMed: 20397444]

18. Henderson JL, Price SH, Brandstater ME, Mandac BR. Efficacy of three measures to relieve pressure in seated persons with spinal cord injury. Archives of Physical Medicine \& Rehabilitation 1994;75(5):535-539. [PubMed: 8185445]

19. Burns SP, Betz KL. Seating pressures with conventional and dynamic wheelchair cushions in tetraplegia. Archives of Physical Medicine \& Rehabilitation 1999;80(5):566-571. [PubMed: 10326923]

20. Vaisbuch N, Meyer S, Weiss PL. Effect of seated posture on interface pressure in children who are able-bodied and who have myelomeningocele. Disability and Rehabilitation 2000 Nov;22(17): 749-755. [PubMed: 11194615]

21. Michael SM, Porter D, Pountney TE. Tilted seat position for non-ambulant individuals with neurological and neuromuscular impairment: a systematic review. Clinical Rehabilitation 2007;21(12):1063-1074. [PubMed: 18042602]

22. Maurer CL, Sprigle S. Effect of seat inclination on seated pressures of individuals with spinal cord injury. Physical Therapy 2004 Mar;84(3):255-261. [PubMed: 14984297]

23. Koo TK, Mak AF, Lee YL. Posture effect on seating interface biomechanics: comparison between two seating cushions. Archives of Physical Medicine \& Rehabilitation 1996;77(1):40-47. [PubMed: 8554472]

24. Gefen A, Levine J. The false premise in measuring body-support interface pressures for preventing serious pressure ulcers. Journal of Medical Engineering \& Technology 2007;31(5):375-380. [PubMed: 17701783]

25. Coggrave MJ, Rose LS. A specialist seating assessment clinic: changing pressure relief practice. Spinal Cord 2003;41(12):692-695. [PubMed: 14639449]

26. Sonenblum SE, Sprigle S, Maurer CL. Use of power tilt systems in everyday life. Disability and Rehabilitation: Assistive Technology 2009;4(1):24-30. [PubMed: 19172478]

27. Sachse RE, Fink SA, Klitzman B. Multimodality evaluation of pressure relief surfaces. Plastic \& Reconstructive Surgery 1998;102(7):2381-2387. [PubMed: 9858173]

28. Jan YK, Brienza DM, Geyer MJ, Karg P. Wavelet-based spectrum analysis of skin blood flow response to alternating pressure. Archives of Physical Medicine \& Rehabilitation 2008;89(1):137145. [PubMed: 18164343] 
29. Bogie KM, Nuseibeh I, Bader DL. Early progressive changes in tissue viability in the seated spinal cord injured subject. Paraplegia 1995;33(3):141-147. [PubMed: 7784116]

30. Frantz RA, Xakellis GC. Characteristics of skin blood flow over the trochanter under constant, prolonged pressure. American Journal of Physical Medicine \& Rehabilitation 1989;68(6):272276. [PubMed: 2686716]

31. Jan YK, Brienza DM, Boninger ML, Brenes G. Comparison of skin blood flow response with alternating and constant pressures in people with spinal cord injury. Spinal Cord. 2010 DOI: $10.1038 /$ sc.2010.1058.

32. Makhsous M, Priebe M, Bankard J, Rowles D, Zeigler M, Chen D, et al. Measuring tissue perfusion during pressure relief maneuvers: insights into preventing pressure ulcers. Journal of Spinal Cord Medicine 2007;30(5):497-507. [PubMed: 18092567]

33. Schubert V, Fagrell B. Postocclusive reactive hyperemia and thermal response in the skin microcirculation of subjects with spinal cord injury. Scandinavian Journal of Rehabilitation Medicine 1991;23(1):33-40. [PubMed: 2035001]

34. Dicianno BE, Arva J, Lieberman JM, Schmeler MR, Souza A, Philips K, et al. RESNA position on the application of tilt, recline, and elevating legrests for wheelchairs. Assistive Technology 2009;21:13-22. [PubMed: 19719059]

35. Oberg PA. Laser-Doppler flowmetry. Critical Review in Biomedical Engineering 1990;18(2):125163.

36. Jan YK, Brienza DM, Geyer MJ. Analysis of week-to-week variability in skin blood flow measurements using wavelet transforms. Clinical Physiology \& Functional Imaging 2005;25(5): 253-262. [PubMed: 16117727]

37. Bircher A, de Boer EM, Agner T, Wahlberg JE, Serup J. Guidelines for measurement of cutaneous blood flow by laser Doppler flowmetry. A report from the Standardization Group of the European Society of Contact Dermatitis. Contact Dermatitis 1994;30(2):65-72. [PubMed: 8187504]

38. Ding D, Leister E, Cooper RA, Cooper R, Kelleher A, Fitzgerald SG, et al. Usage of tilt-in-space, recline, and elevation seating functions in natural environment of wheelchair users. Journal of Rehabilitation Research and Development 2008;45(7):973-983. [PubMed: 19165687]

39. Mayrovitz HN, Sims N. Effects of different cyclic pressurization and relief patterns on heel skin blood perfusion. Advances in Skin \& Wound Care 2002;15(4):158-164. [PubMed: 12151981]

40. Bliss MR. Hyperaemia. Journal of Tissue Viability 1998;8(4):4-13. [PubMed: 10480965]

41. Lewis T, Grant R. Observations upon reactive hyperaemia in man. Heart 1926;12:73-120.

42. Mayrovitz HN, Sims N, Taylor MC, Dribin L. Effects of support surface relief pressures on heel skin blood perfusion. Advances in Skin \& Wound Care 2003;16(3):141-145. [PubMed: 12789036]

43. Zhang M, Roberts VC. The effect of shear forces externally applied to skin surface on underlying tissues. Journal of Biomedical Engineering 1993;15(6):451-456. [PubMed: 8277747]

44. Rendell MS, Wells JM. Ischemic and pressure-induced hyperemia: a comparison. Archives of Physical Medicine \& Rehabilitation 1998;79:1451-1455. [PubMed: 9821909]

45. Engelke KA, Halliwill JR, Proctor DN, Dietz NM, Joyner MJ. Contribution of nitric oxide and prostaglandins to reactive hyperemia in human forearm. Journal of Applied Physiology 1996;81(4):1807-1814. [PubMed: 8904603]

46. Harris F, Sprigle S, Sonenblum SE, Maurer CL. The participation and activity measurement system: an example application among people who use wheeled mobility devices. Disability and Rehabilitation: Assistive Technology 2010;5(1):48-57. [PubMed: 19941440]

47. Dinsdale SM. Decubitus ulcers: role of pressure and friction in causation. Archives of Physical Medicine \& Rehabilitation 1974;55(4):147-152. [PubMed: 4595834]

48. Pellow TR. A comparison of interface pressure readings to wheelchair cushions and positioning: a pilot study. Canadian Journal of Occupational Therapy 1999;66:140-149.

49. Aissaoui R, Kauffmann C, Dansereau J, de Guise JA. Analysis of pressure distribution at the bodyseat interface in able-bodied and paraplegic subjects using a deformable active contour algorithm. Medical Engineering \& Physics 2001;23(6):359-367. [PubMed: 11551812] 
(a) Tilt-in-space angle

Figure 1. (b) Recline angle

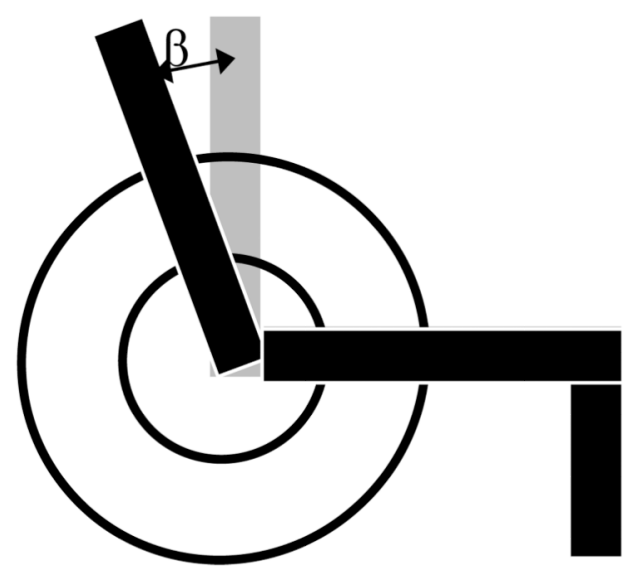

Configurations of wheelchair tilt-in-space and recline. (a) The angle $\alpha$ indicates the wheelchair tilt-in-space angle. (b) The angle $\beta$ indicates the wheelchair recline angle. 

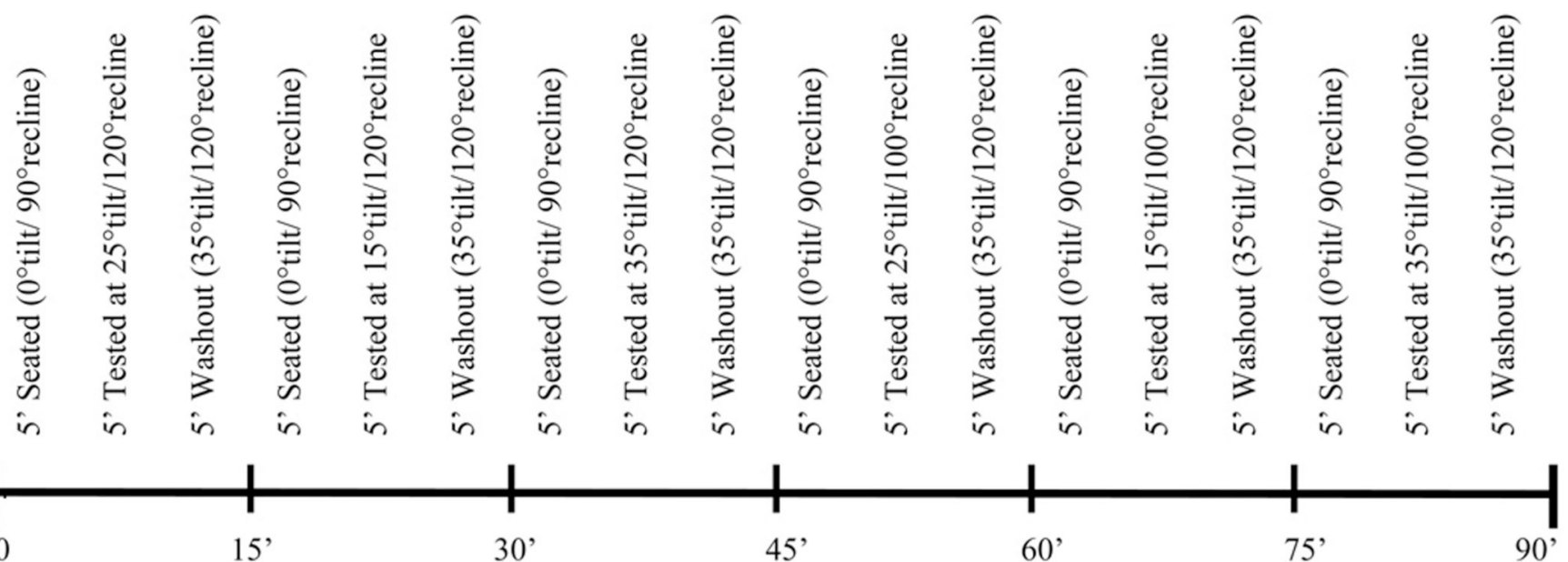

Figure 2.

An example of a complete testing protocol for a resarch participant. It takes 90 minutes to complete all protocols for one participant. 


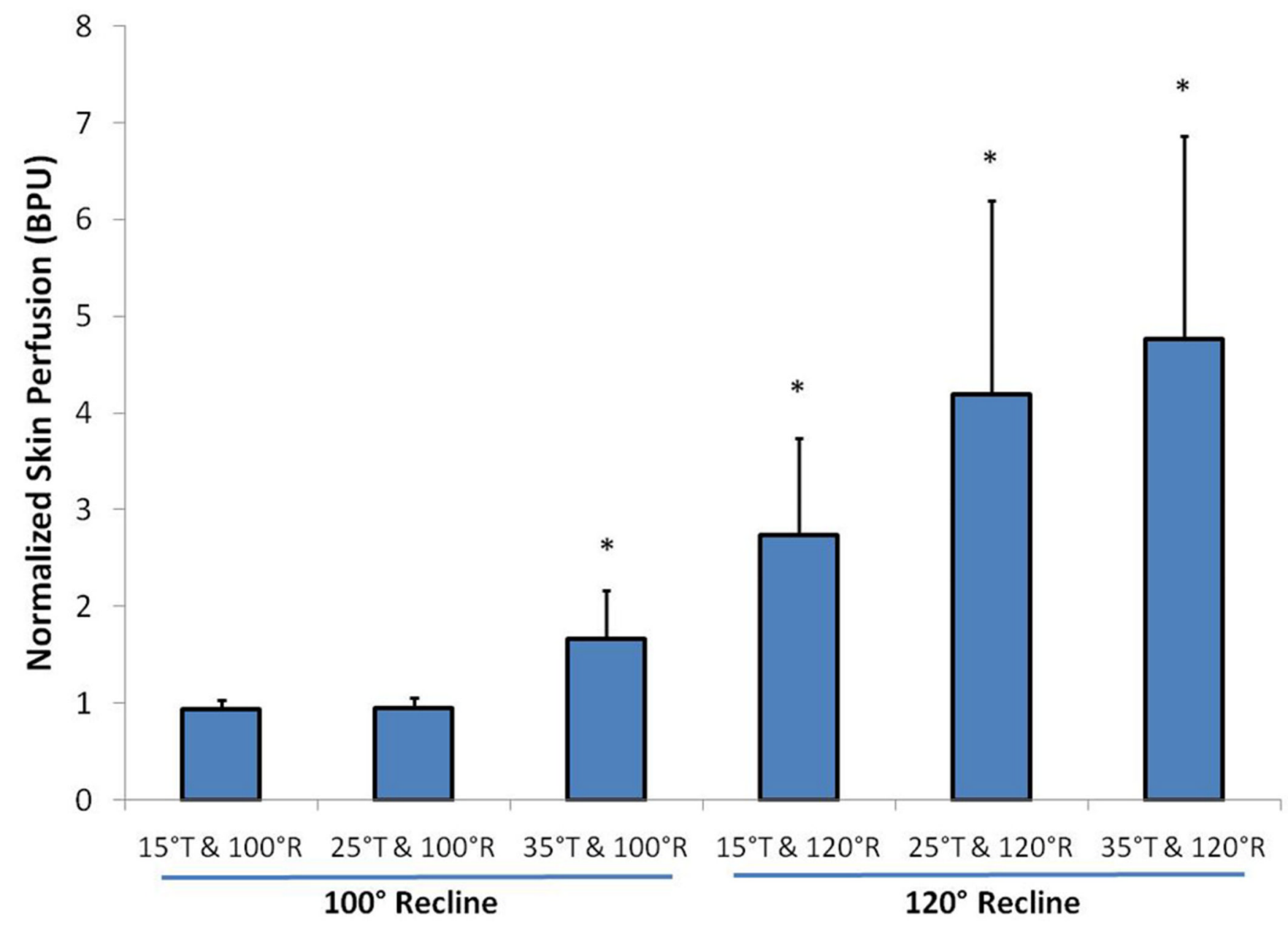

\section{Figure 3.}

Comparison of skin perfusion in response to wheelchair tilt-in-space $\left(15^{\circ}, 25^{\circ}\right.$, and $\left.35^{\circ}\right)$ in combination with recline $\left(100^{\circ}\right.$ and $\left.120^{\circ}\right)$. During tilted and reclined positions, 4 testing positions showed a significant increase in skin perfusion as compared with the upright seated position $(\mathrm{p}<0.05)$; while positions at $15^{\circ}$ tilt-in-space and $100^{\circ}$ recline and $25^{\circ}$ tilt-inspace and $100^{\circ}$ recline did not show a significant increase in skin perfusion. When combined with $100^{\circ}$ recline, wheelchair tilt-in-space at $35^{\circ}$ resulted in a significant increase in skin perfusion as compared with wheelchair tilt-in-space at $15^{\circ}$ and $25^{\circ}(\mathrm{p}<0.05)$; while no significant difference between $15^{\circ}$ and $25^{\circ}$. When combined with $120^{\circ}$ recline, wheelchair tilt-in-space at 35 resulted in a significant increase in skin perfusion when compared with $15^{\circ}$ tilt-in-space $(\mathrm{p}<0.05)$. (* indicates $\mathrm{p}<0.05$; $\mathrm{T}$ means tilt-in-space and $\mathrm{R}$ means recline. Data are shown in the mean values plus standard error.) 
Table 1

A repeated measure design of wheelchair tilt-in-space and recline angles.

\begin{tabular}{|c|c|c|c|}
\hline & \multicolumn{3}{|c|}{ Wheelchair Tilt-in-space Angle $(\mathbf{A})$} \\
\hline Wheelchair recline angle $(\mathbf{B})$ & $\mathbf{1 5}^{\circ}$ tilt $\left(\mathbf{A}_{\mathbf{1}}\right)$ & $\mathbf{2 5}^{\circ}$ tilt $\left(\mathbf{A}_{\mathbf{2}}\right)$ & $\mathbf{3 5}^{\circ}$ tilt $\left(\mathbf{A}_{\mathbf{3}}\right)$ \\
\hline $100^{\circ}$ recline $\left(\mathrm{B}_{1}\right)$ & $\mathrm{A}_{1} \mathrm{~B}_{1}$ & $\mathrm{~A}_{2} \mathrm{~B}_{1}$ & $\mathrm{~A}_{3} \mathrm{~B}_{1}$ \\
\hline $120^{\circ}$ recline $\left(\mathrm{B}_{2}\right)$ & $\mathrm{A}_{1} \mathrm{~B}_{2}$ & $\mathrm{~A}_{2} \mathrm{~B}_{2}$ & $\mathrm{~A}_{3} \mathrm{~B}_{2}$ \\
\hline
\end{tabular}




\begin{tabular}{|c|c|c|c|c|c|c|c|c|c|c|c|}
\hline$\dot{\theta}$ & 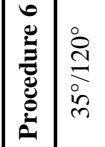 & $\mid$ & & 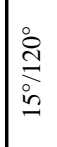 & 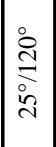 & $\frac{\stackrel{\circ}{c}}{i}$ & $\left|\begin{array}{c}0 \\
\stackrel{8}{1} \\
i \\
i n n \\
m\end{array}\right|$ & $\mid \begin{array}{c}0 \\
\stackrel{8}{7} \\
i \\
i \\
i\end{array}$ & $\frac{8}{8}$ & & \\
\hline $\begin{array}{l}0 \\
0 \\
0 \\
00 \\
0 \\
0\end{array}$ & 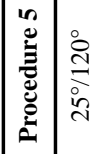 & 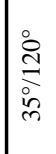 & 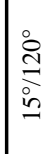 & & 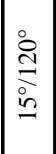 & 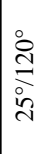 & $\mid \begin{array}{c}0 \\
\stackrel{8}{7} \\
i \\
i \\
i\end{array}$ & 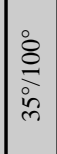 & $\frac{8}{8}$ & $\frac{8}{8}$ & 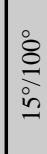 \\
\hline 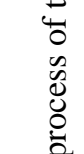 & 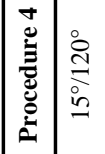 & 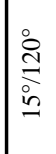 & & & 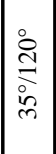 & $\frac{\stackrel{o}{\tilde{y}}}{\stackrel{i}{i}}$ & $\frac{8}{8}$ & $\begin{array}{l}\stackrel{8}{\circ} \\
\text { in }\end{array}$ & $\frac{8}{8}$ & & 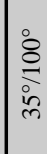 \\
\hline 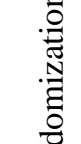 & 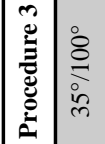 & 送 & & 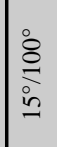 & 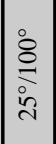 & $\begin{array}{l}0 \\
\stackrel{8}{1} \\
i \\
i\end{array}$ & 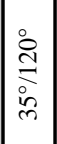 & 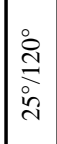 & 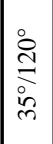 & $\mid \begin{array}{c}0 \\
\text { ì } \\
\text { in } \\
\text { in }\end{array}$ & 尊 \\
\hline 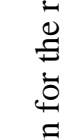 & 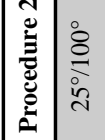 & 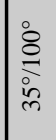 & & 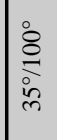 & 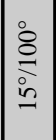 & $\begin{array}{l}0 \\
\stackrel{8}{8} \\
\stackrel{8}{i} \\
i\end{array}$ & 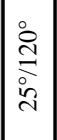 & 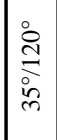 & $\frac{\stackrel{2}{0}}{\stackrel{i}{1}}$ & & \\
\hline 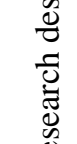 & 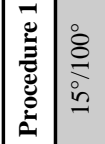 & & 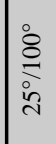 & & $\mid \begin{array}{c}0 \\
\stackrel{8}{1} \\
i \\
i \\
m\end{array}$ & $\begin{array}{l}\stackrel{0}{a} \\
\stackrel{8}{i} \\
i m \\
m\end{array}$ & 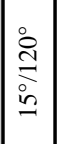 & 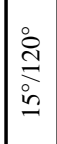 & 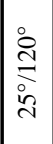 & & \\
\hline 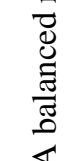 & 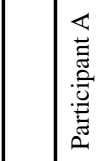 & 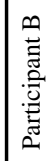 & 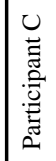 & 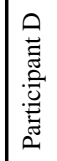 & 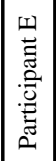 & 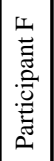 & 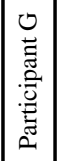 & 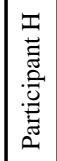 & 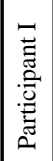 & 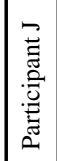 & 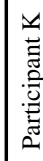 \\
\hline
\end{tabular}

